\title{
ANALISIS KUALITAS AIR DI PANTAI DUWET KECAMATAN PANARUKAN SEBAGAI UJI PENDAHULUAN STATUS KEAMANAN BUDIDAYA ALGA ULVA
}

\section{ANALYSIS OF WATER QUALITY IN DUWET BEACH IN PANARUKAN DISTRICT AS A PRELIMINARY TEST OF THE SAFETY STATUS OF ULVA ALGAE CULTIVATION}

\author{
Ani Listriyana ${ }^{1)}$ Anita Diah Pahlewi ${ }^{2)}$ \\ 1alistriyana@gmail.com ${ }^{1}$ \\ ${ }^{1,2}$ Universitas Abdurachman Saleh Situbondo
}

\begin{abstract}
ABSTRAK
Penelitian ini untuk mengetahui kualitas air di perairan pantai Duwet kecamatan Panarukan. Pengambilan sampel dilakukan di tiga titik, yaitu L1,L2 dan L3 dan prosesnya dilakukan saat pasang dan saat surut. Adapun parameter yang diukur antara lain Suhu, pH, oksigen terlarut (DO), kadar nitrit dan kadar amonia. Secara umum, oksigen terlarut cukup banyak sehingga memungkinkan biota laut untuk berkembangbiak. Kadar amonia di LP2 dan LP3 memenuhi standar baku mutu lingkungan sedangkan kadar amonia di LP1, LS1, LS2, LS3 di atas baku mutu lingkungan dan ini cukup membayakan karena bersifat toksik. Hal ini disebabkan karena terdapat buangan limbah yang belum dikelola secara maksimal oleh pemilik tambak dan terdapat beberapa kotoran sapi yang dibuang di pinggir pantai. Selain memberikan edukasi kepada pemilik ternak sapi dan negosiasi dengan pihak tambak, untuk mengurangi limbah warga harus mengambil Ulva saat kondisi pasang.
\end{abstract}

Keyword :alga ulva, amonia, DO, pasang, surut

\begin{abstract}
This research is to find out the water quality in the coastal waters of Duwet, Panarukan district. Sampling was carried out at three points namely L1, L2 and L3 and each was carried out of high tide and at low tide. The parameters measured include temperature, $\mathrm{pH}$, dissolved oxygen (DO), nitrite levels and ammonia levels. In general, dissolved oxygen is sufficient to allow marine biota to multiply. Ammonia levels in LP2 and LP3 meet environmental quality standards while for ammonia levels in LP1, LS1, LS2, LS3 above the environmental quality standard which means this is quite dangerous because it is toxic. This can be caused by the fact that there is a waste disposal that has not been treated optimally by the owner of the pond and there are some cow dung which is dumped along the beach. In addition to educating cattle owners and negotiating with farmers, what must be done now by residents is taking Ulva during high tide.
\end{abstract}

Keyword: algae ulva, ammonia, DO, high tide, low tide 


\section{PENDAHULUAN}

Limbah merupakan bagian yang tidak dapat dipisahkan dari kehidupan manusia, terutama limbah domestik yang merupakan hasil samping dari kegiatan aktivitas manusia. Peningkatan konsentrasi bahan kimia tertentu seperti amoniak dan nitrat $\left(\mathrm{NO}_{3^{-}}\right)$di dalam badan air karena air limbah adalah salah satu masalah pencemaran badan air.

Disamping itu Situbondo merupakan daerah di mana sebagian masyarakatnya berprofesi sebagai nelayan dan pengusaha ikan. Pengusaha ikan biasanya memiliki tambak atau hatchery dan tidak semua tambak di lengkapi dengan PAL. Secara otomatis ini akan menambah konsentasi nitrat dalam badan air laut. Padahal konsentrasi nitrat $\left(\mathrm{NO}_{3}-\right)$ yang tinggi dapat mempengaruhi kualitas air dan mengganggu kehidupan biota air didalamnya. Pengolahan limbahsecara konvensional baik secara kimiawi maupun biologis telah banyak diterapkan, namun pengolahan tersebut memiliki beberapa kelemahan antara lain biaya yang dibutuhkan untuk bahan kimia maupun desain bangunan relatif mahal. Hasil samping dari pengolahan tersebut berupa lumpur yang masih membutuhkan pengolahan lebih lanjut.Sehingga rata-rata pengusaha tambak tidak menerapkan metode ini.

Saat ini mulai dikembangkan metode pengolahan limbah secara alamiah yang lebih sederhana dengan memanfaatkan tanaman air / organisme air.Pengolahan dengan metode ini dapat digunakan sebagai alternatif pengolahan yang lebih murah dibandingkan pengolahan secara konvensional. Alga hijau (Chlorella $s p$ ) merupakan tumbuhan yang dapat dijadikan alternatif pengolahan limbah karena selain biaya pengolahan lebih rendah, pengolahan ini tidak menghasilkan lumpur yang membutuhkan pengolahan lebih lanjut. Disisi lain nitrat $\left(\mathrm{NO}_{3}{ }^{-}\right)$merupakan nutrisi yang dibutuhkan oleh setiap organisme air khususnya alga hijau (Chlorella sp) dalam melakukan biosintesa.

Di daerah pantai pathek yang kami temui banyak jenis Alga hijau Ulva Sp. Di Pantai Pathek selatan selain sampah domestik juga terdapat saluran buangan limbah dari tambak. 


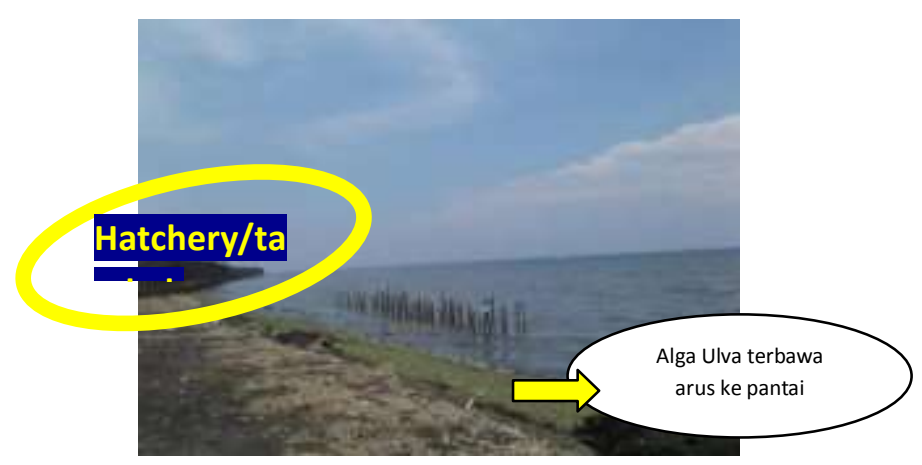

Gambar 1. Terdapat Tambak. diPantai Pathek selatan

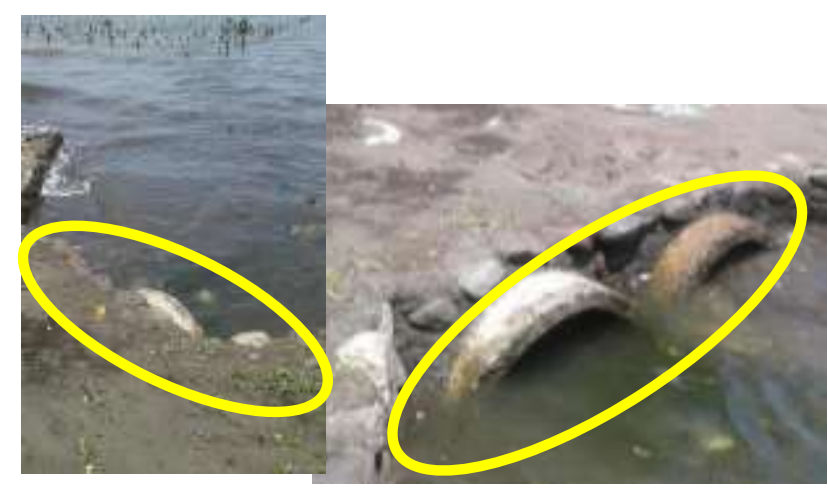

Gambar.2. Saluran Pembuangan Limbah di Pantai Pathek Selatan saat kondisi pasang

Berdasarkan hasil pengamatan secara kasat mata, ikan-ikan kecil sudah tidak ada lagi di pantai Pathek selatan. Untuk mencari ulva yang nantinya akan di jual pun mereka harus menunggu air surut dan mencari alga ulva agak ke tengah laut. Dan Masyarakat menjual alga ini untuk produk kosmetik ke Surabaya dan saat ini mulai dikembangkan produk olahan dari alga ulva ini menjadi stik nori. Kami ingin mencoba mengetahui kualitas air di sekitar tumbuhnya ulva ini untuk status awal keamanan alga ulva dari pencemaran agar produk yang dihasilkan juga bermanfaat untuk masyarakat luas. 


\section{METODE PENELITIAN}

Pengambilan sampel dilakukan tanggal 29 April jam 14.40 saat kondisi surut dan tanggal 30 April jam 07.40 saat kondisi pasang dengan lokasi penelitian di Pantai Pathek Selatan Situbondo dengan jarak sekitar $11 \mathrm{~km}$ dari kampus UNARS.

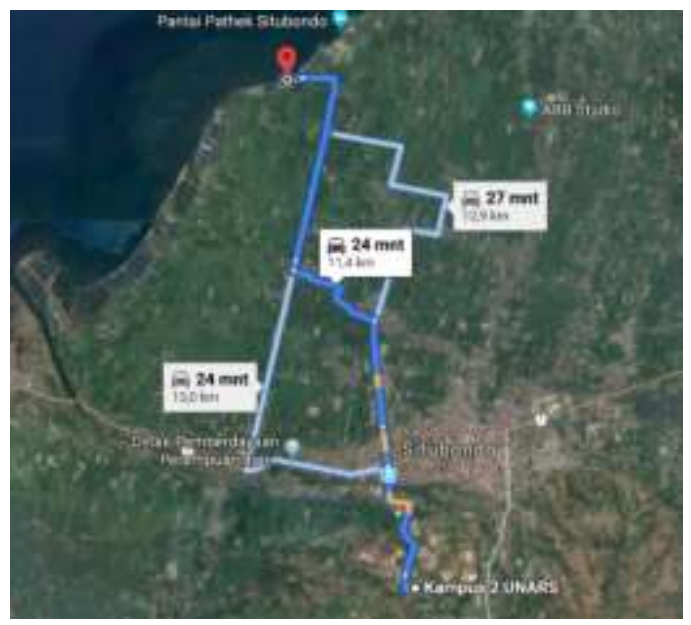

Gambar 3.Lokasi penelitian di pantai pathek selatan

Ada beberapa varibel yang kami rencanakan dalam penelitian ini di antaranya Variabel bebas meliputi : Suhu, PH, salinitas, DO, kadar nitrit, kadar amoniak Variabel terikat meliputi : Status pencemaran

Untuk rancangan penelitian dititik beratkan pada

\section{Lokasi Pengambilan sampel}

Lokasi pengambilan sampel di 2 pantai yaitu dapat dilihat pada tabel berikut

\begin{tabular}{|l|l|c|c|c|}
\hline Lokasi & \multicolumn{1}{|c|}{$\begin{array}{c}\text { Titik pengambilan sampel } \\
\text { Pumlah } \\
\text { Titik }\end{array}$} & $\begin{array}{c}\text { Jumlah } \\
\text { pengujian }\end{array}$ & Total Uji \\
\hline \multirow{2}{*}{$\begin{array}{l}\text { Pathek } \\
\text { selatan }\end{array}$} & $\begin{array}{l}\text { Pantai(air di titik saluran limbah) }= \\
\text { L1 }\end{array}$ & 1 & 2 & 2 \\
\cline { 2 - 5 } & Tengah Pantai 1 = L2 & 1 & 2 & 2 \\
\cline { 2 - 5 } & Tengah Pantai 2= L3 & 1 & 2 & 2 \\
\hline \multicolumn{2}{|c|}{ Total sampel } \\
\hline
\end{tabular}


Pengambilan sampel dilakukan saat pasang dan saat surut sehingga total ada 12 pengujian sampel air.

2. Uji pada masing-masing sampel

Adapun pengukuran yang dilakukan pada masing-masing sampel meliputi Suhu, Salinitas, pH, DO, Kadar Nitrit dan Kadar Amonia.

Data hasil uji sampel air yang diperoleh di sesuaikan dengan baku mutu lingkungan yang baik untuk air laut sehingga dari sana kita dapat menganalisis apakah lingkungan perairan pathek masih status aman atau sudah masuk status tercemar terutama untuk status keamanan/keberlanjutan hidup ikan dan alga ulva.

\section{HASIL PENELITIAN}

Pengambilan sampel dilakukan di tiga titik yang berbeda yaitu

Lokasi 1 : dekat lubang limbah dari tambak dengan titik koordinat $7^{\circ} 38^{\prime} 57.7^{\prime \prime S}$ $113^{\circ} 58^{\prime} 51.8^{\prime \prime} \mathrm{E}$

Lokasi 2: 7³8'56.6"S 113ํำ'51.2"E

Lokasi 3: 7³8'56.7"S 11358'50.6"E

Dipilihnya sampel dari L1, L2 dan L3 karena di L1 terdapat saluran pem buangan limbah tambak sedangkan L2 dan L3 lokasi di mana mulai banyak Alga ulva yang tumbuh.

Adapun hasil uji sampelnya adalah sebagai berikut

Tabel 1. Suhu pada Perairan Pantai Pathek Selatan

\begin{tabular}{|c|c|c|c|}
\hline \multirow{2}{*}{$\begin{array}{c}\text { Temp } \\
\text { at }\end{array}$} & \multicolumn{3}{|c|}{ Suhu $\left(^{\mathbf{}} \mathbf{C}\right)$} \\
\hline LP1 & Uji ke-1 & Uji ke-2 & Rata \\
\hline LP2 & 28 & 28 & 28 \\
\hline LP3 & 27,5 & 28 & 28 \\
\hline LS1 & 31 & 31,5 & 27,5 \\
\hline LS2 & 30 & 30 & 31 \\
\hline LS3 & 29,5 & 29,5 & 29,5 \\
\hline
\end{tabular}


Tabel 2. Kadar Keasaman (pH) pada Perairan Pantai Pathek Selatan

\begin{tabular}{|c|c|c|c|}
\hline \multirow{2}{*}{ Tempat } & \multicolumn{3}{|c|}{ Kadar pH } \\
\cline { 2 - 4 } & Uji ke-1 & Uji ke-2 & Rata \\
\hline LP1 & 8,10 & 7,92 & 8,01 \\
\hline LP2 & 8,00 & 7,87 & 7,94 \\
\hline LP3 & 7,94 & 7,41 & 7,68 \\
\hline LS1 & 7,79 & 7,85 & 7,82 \\
\hline LS2 & 7,92 & 7,98 & 7,95 \\
\hline LS3 & 7,60 & 7,91 & 7,75 \\
\hline
\end{tabular}

Tabel 3. Kadar Oksigen Terlarut pada Perairan Pantai Pathek Selatan

\begin{tabular}{|c|c|c|c|}
\hline \multirow{2}{*}{ Tempat } & \multicolumn{3}{|c|}{ DO (mg/L) } \\
\cline { 2 - 4 } & Uji ke-1 & Uji ke-2 & Rata \\
\hline LP1 & 7,55 & 7,66 & 7,61 \\
\hline LP2 & 7,02 & 6,45 & 6,74 \\
\hline LP3 & 6,61 & 6,77 & 6,69 \\
\hline LS2 & 7,66 & 9,11 & 8,39 \\
\hline LS3 & 7,26 & 8,47 & 7,87 \\
\hline
\end{tabular}

Tabel 4. Kadar Nitrit pada Perairan Pantai Pathek Selatan

\begin{tabular}{|c|c|c|c|}
\hline \multirow{2}{*}{ Tempat } & \multicolumn{3}{|c|}{ Kadar Nitrit (mg/L) } \\
\cline { 2 - 4 } & Uji ke-1 & Uji ke-2 & Rata \\
\hline LP1 & 0,242 & 0,223 & 0,2325 \\
\hline LP2 & 0,239 & 0,140 & 0,1895 \\
\hline LP3 & 0,084 & 0,090 & 0,087 \\
\hline LS1 & 0,356 & 0,366 & 0,361 \\
\hline LS2 & 0,367 & 0,370 & 0,369 \\
\hline LS3 & 0,409 & 0,409 & 0,409 \\
\hline
\end{tabular}


Tabel 5. Kadar Amonia Total pada Perairan Pantai Pathek Selatan

\begin{tabular}{|c|c|c|c|}
\hline \multirow{2}{*}{ Tempat } & \multicolumn{3}{|c|}{ Kadar Amoniak Total (mg/L) } \\
\cline { 2 - 4 } & Uji ke-1 & Uji ke-2 & Rata \\
\hline LP1 & 0,403 & 0,412 & 0.408 \\
\hline LP2 & 0,202 & 0,135 & 0,169 \\
\hline LP3 & 0,276 & 0,189 & 0,233 \\
\hline LS1 & 0,516 & 0,637 & 0,578 \\
\hline LS2 & 0,807 & 0,863 & 0,835 \\
\hline LS3 & 0,562 & 0,712 & 0,637 \\
\hline
\end{tabular}

Kadar DO, di semua lokasi di atas 5 yang artinya kadar oksigen terlarut cukup melimpah untuk keberlangsungan organisme yang ada di dalam perairan ini. Untuk amonia, hanya di LP2 dan LP3 yang menunjukkan kondisi aman di mana kadar amonia masih di bawah ambang batas yaitu $0.169 \mathrm{mg} / \mathrm{L}$ untuk sampel di lokasi 2 saat kondisi pasang dan $0.233 \mathrm{mg} / \mathrm{L}$ untuk sampel di lokasi 3 saat kondisi pasang. Sedangkan di LP1, LS1, LS2, dan LS3 menunjukkan kadar amoniak di atas ambang batas baku mutu lingkungan laut di mana batas maksimal amonia total adalah $0.3 \mathrm{mg} / \mathrm{L}$. LP1 lebih tinggi $36 \%$ dari batas ambang batas. Saat kondisi surut, kader amoniak di LS2>LS3>LS1. LS1 92,6\% lebih tinggi dari ambang batas, LS2 178\% lebih tingi dari ambang batas dan LS3 lebih tinggi $112 \%$ dari ambang batas. Jika dilihat dari lokasinya , L2 lurus dengan L1 lokasi di mana terdapat saluran pembuangan limbah dari pabrik. Sedangan L3 berada 11 meter dari L2.

Secara bathimetri, aliran menuju L2 lebih rendah daripada aliran dari L1 menuju L3 sehingga aliran dari buangan limbah saat surut akan lebih banyak terkonsentrasi pada L2 dan mengalir juga menuju L3. Sedangkan saat pasang, kondisi air jauh lebih banyak di banding dengan limbah yang ada sehingga di mungkinkan limbah menyebar ke banyak tempat .

Amonia dan garam-garamnya mudah larut dalam air .Ion amonium adalah bentuk transisi dari amonia. Amonia banyak digunakan dalam proses produksi 
urea, industri bahan kima, serta industri bubur kertas. Tinja dari biota akutik dan hewan ternak yang merupakan limbah aktivitas metabolisme juga banyak mengeluarkan amonia. Sumber amonia yang lain adalah reduksi gas nitrogen yang berasal dari proses difusi udara atmosfer, limbah industri dan domestik.

Di perairan alami, pada suhu dan tekanan normal amonia berada dalam bentuk gas dan membentuk keseimbangan dengan ion amonium. Amonia yang terukur di perairan berupa amonia total (NH3 dan NH4+). Amonia bebas tidak dapat terionisasi (Amoniak) dengan amonium dapat terionisasi.Perssentasi amonia meningkat dengan meningkatnya nilai $\mathrm{pH}$ dan suhu perairan. Pada $\mathrm{pH} 7$ atau kurang, sebagian besar amonia akan mengalami ionisasi. Sebaliknya pada pH lebih besar dari 7 amonia tidak terionisasi yang dapat bersifat toksik dalam jumlah banyak.Amonia bebas yang tidak berionisasi bersifat toksik terhadap organisme akuatik. Toksisitas amoniak akan meningkat jika terjadi penurunan kadar oksigen terlarut (DO). $\mathrm{pH}$ dan suhu.

Untuk kasus di lokasi ini ada beberapa kemungkinan penyebab meningkatnya kadar amoniak yakni karena buangan limbah dari tambak dan terdapat kotoran sapi di dekat lokasi pembuangan limbah.

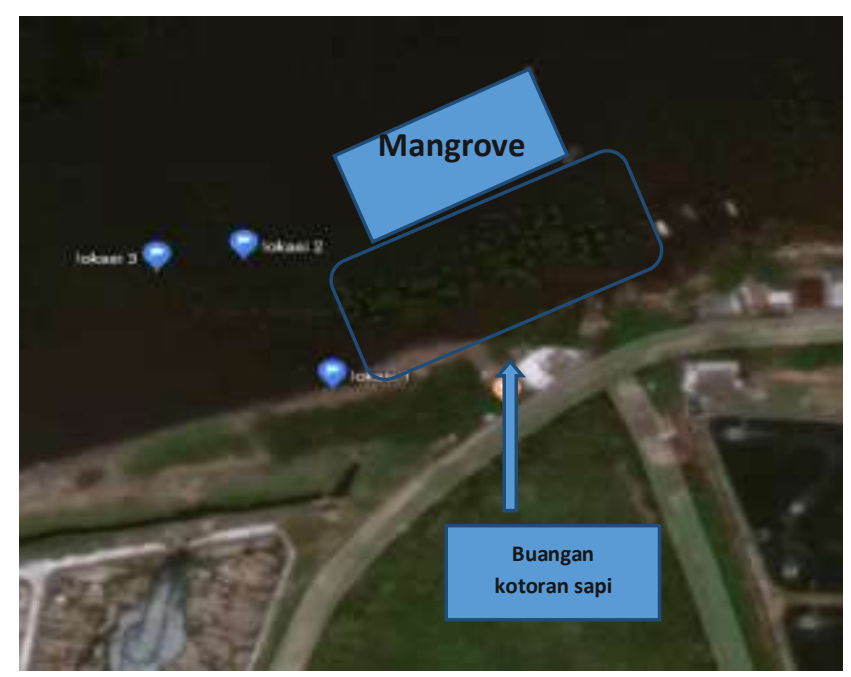

Gambar4. Lokasi mangrove dan pembuangan kotoran sapi 
Di lokasi yang tertera pada peta terdapat rumah warga sekaligus warung di mana mereka juga memiliki ternak sapi dan setelah selesai melakukan pengamatan secara laboratorium, kami baru melihat ada kotoran sapi yang dibuang di pinggir pantai yang tentunya akan terbawa ke tengah laut ketika terjadi pasang. Kondisi ini cukup tertolong dengan adanya mangrove yang menghalang kotoran bebas ke tengah laut. Di samping itu dengan fungsi mangrove sebagai adsorben bahan-bahan kimia berbahaya seharusnya dapat mengurangi kadar amonia yang ada, Namun hal ini butuh penelitian lebih lanjut.

\section{KESIMPULAN}

Dari penelitian yang kami dapat diambil beberapa kesimpulan yakni

1. Kondisi kualitas air perairan, dari uji laboratorium menunjukkan bahwa oksigen terlarut cukup banyak untuk kebutuhan organisme di perairan pantai pathek selatan, desa duwet. Akan tetapi kandungan amonia yang cukup tinggi terutama di saat surut pada L1 lokasi dekat limbah pembuangan, L2 serta L3 yang berada agak ke tengah laut. Kondisi ini dapat disebabkan oleh buangan dari limbah tambak dan limbah kotoran sapi yang dibuang dipinggir pantai oleh salah satu warga. Dengan adanya mangrove di sekitar lokasi, diharapkan dapat meminimalisir zat berbahaya dari limbah yang ada

2. Saat kondisi pasang, kadar amonia cukup tinggi di L1 dan di bawah ambang batas untuk L2 dan L3 sehingga ulva cukup aman di lokasi L2 dan L3 saat pasang di bandingkan saat surut

3. Sebaiknya yang dilakukan warga adalah dengan mengambil atau memanen ulva saat pasang berlangsung 


\section{DAFTAR PUSTAKA}

Ali, Munawar. 2013. DEGRADASI NITRAT LIMBAH DOMISTIK DENGAN ALGA HIJAU (Chlorella sp).Surabaya : UPN

Sunu, P. 2001. Melindungi Lingkungan dengan Menerapkan ISO 14001. PT Grasindo: Jakarta

Soeparman, 2001.Pembuangan Tinja dan Limbah Cair. Suatu Pengantar : Jakarta

Prabowo, Rossi. . Kadar NItrit Pada Sumber Air Sumur di kelurahan Meteseh, Kec. Tembalang, Kota Semarang. Jurnal Ilmiah Cendekia Eksakta : Semarang

Salmin. 2005. Oksigen Terlarut(DO) dan Kebutuhan Oksigen Biologi (BOD) Sebagai Salah Satu Indikator untuk Menentukan Kualitas Perairan. Osecana, Volume XXX, Nomor 3, 2005:21-26. 